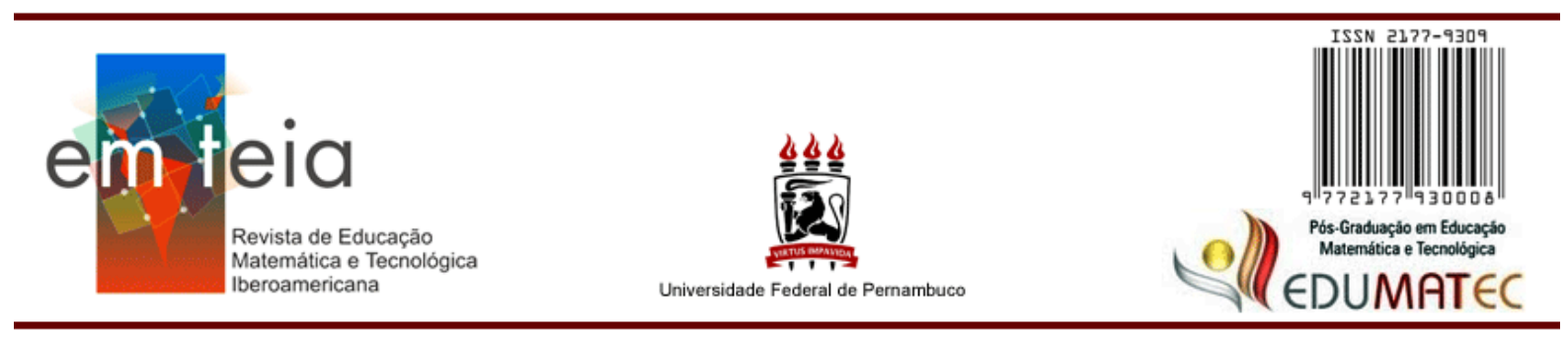

APLICATIVO JOGO BOLSA DE VALORES:

\title{
uma atividade lúdica visando à inclusão da Educação Financeira e tomada de decisão nas aulas de Matemática
}

Stock Exchange Game App:

a ludic activity aiming at the inclusion of Financial Education and decision-making in

\section{Mathematics classes}

\author{
Nelson Machado Barbosa \\ Doutor em Modelagem Computacional \\ Universidade Estadual do Norte Fluminense - UENF \\ barbosa@uenf.br \\ http://orcid.org/0000-0002-0628-1195 \\ Jonatas Campos Sarlo \\ Mestre em Matemática \\ Universidade Estadual do Norte Fluminense - UENF \\ jonatas.sarlo@uenf.br \\ http://orcid.org/0000-0002-9517-2088 \\ Eduardo Corrêa dos Santos \\ Mestre em Matemática \\ Colégio Estadual Pedro Cerqueira - RJ \\ edufilo@yahoo.com.br \\ http://orcid.org/0000-0001-9193-6012
}

\section{Resumo}

$\mathrm{O}$ conhecimento financeiro e as capacidades cognitivas estão, convincentemente, ligados à qualidade da tomada de decisões financeiras. Baseando-se em pesquisas e ações participativas, este artigo apresenta uma prática pedagógica viável para facilitar o desenvolvimento do senso de autonomia do aluno, concentrando-se em envolver ativamente os estudantes no desenvolvimento do entendimento da Educação Financeira contextualizada, trabalhando de forma independente e cooperativa na tomada de decisão em uma situação-problema, com o intuito de propiciar técnicas para uma melhor administração financeira. Com este propósito, é apresentada uma atividade lúdica utilizando um aplicativo chamado Jogo Bolsa de Valores, que simula de forma satisfatória a dinâmica da Bolsa de Valores de São Paulo [B3]. A partir dos resultados, pode-se perceber que ao trabalhar com o pensamento crítico e a tomada de decisão do aluno, foi possível desenvolver hábitos mentais concretos. Os discentes puderam desenvolver os processos cognitivos ensinados, sendo capazes de transferi-los para novas situações em economia, geopolítica e matemática financeira.

Palavras-Chave: Educação Financeira. Investimentos. Bolsa de Valores. Aplicativo. Jogo. 


\begin{abstract}
Financial knowledge and cognitive skills are convincingly linked to the quality of financial decisionmaking. Based on research and participatory actions, this article presents a viable pedagogical practice to facilitate the development of the student's sense of autonomy, focusing on actively involving students in developing an understanding of contextualized Financial Education, working independently and cooperatively in decision making in a problem situation, in order to provide techniques for better financial management. For this purpose, a playful activity is presented using an application called the Stock Exchange Game, which satisfactorily simulates the dynamics of the São Paulo Stock Exchange [B3]. From this result, it can be seen that by working with the student's critical thinking and decision-making, it was possible to develop concrete mental habits. The students were able to develop the cognitive processes taught, being able to transfer them to new situations in economics, geopolitics and financial mathematics.
\end{abstract}

Keywords: Financial Education, investments, Stoke Exchange, app, game.

\title{
Introdução
}

De uma maneira geral, a sociedade brasileira, com sua vertente capitalista, não possui uma cultura de aprender Educação Financeira. Os indivíduos, ainda que de forma não proposital, adquirem o hábito de financiar, parcelar compras, não poupar e não investir. Dados dos relatórios econômicos da Organização para a Cooperação e Desenvolvimento Econômico (OCDE) revelam que a maioria dos trabalhadores brasileiros não seria capaz de manter o padrão de vida, caso ficassem sem receber o seu salário por menos de dois meses. Essa informação demonstra um perfil imediatista na forma de gastar, não priorizando o ato de poupar e investir. A homologação da Base Nacional Comum Curricular (BNCC) (BRASIL, 2018), em meio a esse cenário, trouxe acréscimos no currículo de matemática (e de outras disciplinas escolares), pois obriga, em forma de lei, a inclusão desse conteúdo nas escolas, a partir do ano de 2020.

Os padrões no ensino de matemática, no século XXI, sugerem que os conteúdos sejam listados de acordo com o nível de escolaridade (infantil, fundamental, médio, técnico e superior) devendo haver uma reflexão sobre a necessidade de conectá-los às práticas. No Brasil, o currículo escolar é norteado pela Lei de Diretrizes e Bases da Educação Nacional (LDB, Lei no 9.394/1996) (BRASIL, 2005) e uma das incumbências é proporcionar uma formação básica comum, criando critérios para a elaboração desses currículos, com conteúdos mínimos. Tais orientações descrevem quais conhecimentos os educadores matemáticos, em todos os níveis da Educação Básica, devem desenvolver em seus estudantes. Essas práticas baseiam-se em importantes processos de proficiências e são de grande importância para a 
Educação Matemática. Cabe aos sistemas de ensino e escolas contextualizá-las (BRASIL, 2018).

Com a homologação da BNCC, a Educação Financeira chega às salas de aula, no Brasil, de forma obrigatória e não mais como mera sugestão de abordagem dentro da Matemática Financeira. O desenvolvimento de competências para o conhecimento e habilidades em matemática tendo como pano de fundo a Educação Financeira, desde o ensino fundamental, foi ênfase na última atualização desse documento.

A inclusão da Educação Financeira segue tendências de estudos recentes, segundo a Associação Brasileira dos Educadores Financeiros (ABEFIN). De acordo com a Estratégia Nacional de Educação Financeira - (ENEF), que foi criada com o Decreto Federal 7.397/2010 (BRASIL, 2010), com os resultados da Pesquisa Nacional de Educação Financeira nas Escolas, mais de $80 \%$ dos alunos que tiveram contato com a Educação Financeira conseguem guardar parte do que recebem para planos futuros. Conforme Lopes (2018), "Educação financeira na sala de aula é investir na vida fora da escola". A abordagem desse assunto, nas escolas, propicia ao país gerações educadas financeiramente, que sabem lidar com assuntos relativos ao dinheiro e tomar decisões com lucidez e equilíbrio.

A preparação para esse mundo requer que se aprenda a abordar problemas reais com atitude e confiança. Os alunos precisam desenvolver a vontade de lidar com problemas, embasados no conhecimento que já possuem ou que irão adquirir por conta própria, sem fazer uso de um método de solução pré-aprendido (PATARO; SOUZA, 2012). Para uma educação financeira eficaz é preciso desenvolver neles hábitos mentais que os encorajem a resolver problemas maiores, subdividindo-os em menores e que possam criar uma relação dos novos com aqueles que já foram resolvidos, levando-os a tomar decisões tanto de maneira estratégica quanto flexível.

Mesmo com as alterações do documento BNCC, a visão da disciplina, adotada nos Parâmetros Curriculares Nacionais (PCN) (BRASIL, 1997), continua vigente e está pautada por princípios bem fundamentados construídos ao longo dos anos. Dentre esses princípios vale ressaltar que, conforme os $\mathrm{PCN}$, os recursos didáticos como jogos, computadores entre outros materiais têm um papel importante no processo de ensino e aprendizagem. Contudo, eles precisam estar integrados a situações que levem ao exercício da análise e da reflexão, em última instância, a base da atividade matemática.

Nessa perspectiva, o objetivo principal deste artigo é propor uma prática pedagógica que promova o desenvolvimento do senso de autonomia do estudante, com tomadas de 
decisão que estejam concentradas, ativamente, no envolvimento dele no desenvolvimento do entendimento dos conceitos da Educação Financeira, em especial, na área de investimentos em renda variável, conduzindo-o a investigações e registrando descobertas. Como objetivos específicos espera-se demonstrar a importância da Educação Financeira no cotidiano, ensinando, de forma diferenciada e lúdica, conceitos como: renda variável, investimentos, commodities, Bolsa de Valores, análise de riscos, porcentagem, juros, análise gráfica e conceitos básicos de economia e geopolítica, contribuindo significativamente para a sua formação em Educação Financeira.

Para isso foi utilizado o Aplicativo Jogo Bolsa de Valores, que simula de forma satisfatória a dinâmica da Bolsa de Valores de São Paulo - [B3]. O aplicativo, que pode ser na língua portuguesa, possui uma configuração robusta além de ser gratuito. É o único no mundo com estratégias sobre economia, baseado em diversos eventos geopolíticos aleatórios. Este aplicativo utiliza um sistema único de gestão e treinamento, permitindo a maximização na utilização dos conhecimentos, habilidades e nas tomadas de decisões dos estudantes, indo em consonância pelo proposto na BNCC.

Para atingir os objetivos propostos nesta pesquisa, a experimentação didática foi totalmente envolvida numa metodologia ativa, imerso em um caráter quantitativo e qualitativo, com o uso integrado do Aplicativo Jogo Bolsa de Valores. Através das análises da experimentação, percebeu-se que a prática pedagógica proposta contribuiu significativamente para o aprendizado e a conscientização da Educação Financeira, em especial nas áreas de investimentos e tomada de decisão.

Vale ressaltar que a utilização do Aplicativo Jogo Bolsa de Valores trouxe modernidade e interação a uma geração que está completamente alfabetizada tecnologicamente. Durante o uso de tal ferramenta, vivenciou-se, na prática, uma integração entre a tecnologia e a sala de aula, obtendo resultados satisfatórios.

\section{A inclusão da Educação Financeira: uma visão política e educacional no Brasil}

A Educação Financeira, nas aulas de Matemática, é um tema em ampla discussão pelo governo e com previsão de inclusão na grade escolar. Algumas escolas privadas, em seu currículo, já trabalham com esse conteúdo. O modelo atual de educação vem sendo discutido por especialistas financeiros que enxergam uma deficiência dos brasileiros no conhecimento da matemática financeira básica. 
Não existia no brasileiro comum a cultura de investimento, devido ao baixo poder aquisitivo que não permitia fazer escolhas (CERBASI, 2013, p. 12). Um relevante papel da Educação Financeira é a formação de pessoas mais conscientes e capacitadas em relação à gestão de seus recursos, acompanhando a evolução da economia moderna. Segundo Kioyosaki e Lechter (2000, p. 81), os estudantes saem das escolas instruídos, com sucesso em sua carreira, mas sem nenhuma habilidade financeira e acabam se deparando com dificuldades nessa área, o que os impede de progredirem. Os problemas que eles enfrentam nem sempre estão ligados à falta de dinheiro, todavia de competência para geri-lo.

Entretanto, a Educação Financeira, como uma política pública, vem ganhando espaço no cenário da educação brasileira. O Decreto n ${ }^{\circ}$ 7.397, de 22 de dezembro de 2010 (BRASIL, 2010), deu início a esse caminho com a criação da Estratégia Nacional de Educação Financeira (ENEF). O ENEF foi o ponto de partida para se ter ações integradas e compartilhadas sobre esse assunto, com o intuito de promover a educação financeira e previdenciária da população implicando no fortalecimento da cidadania. Sendo assim, o governo veio atender a uma necessidade de incorporar esse conteúdo na grade curricular do ensino público, uma vez que as escolas do ensino privado já haviam percebido tal carência. Indo ao encontro de uma tendência mundial, o Governo desenvolveu essa política tendo como objetivo fomentar a Educação Financeira nas escolas do ensino básico.

Neste cenário de inclusão, também deve-se destacar a Organização para a Cooperação e o Desenvolvimento Econômico (OCDE, 2019) sendo esta um foro com participação de 35 países que trabalham para promover o desenvolvimento econômico e o bem-estar social, através do desenvolvimento de padrões convergentes em diferentes temas como questões econômicas, financeiras, comerciais, sociais e ambientais. Seus encontros permitem discussões, debates e trocas de experiências na coordenação de políticas governamentais.

O Ministério de Educação e Cultura (MEC) mantém parcerias com a OCDE, com objetivo de promover políticas públicas visando a melhoria da Educação Financeira no Brasil. Essa organização é formada por países desenvolvidos, com elevado valor do PIB (produto interno bruto) e tem seu desenvolvimento econômico alinhado à sustentabilidade.

Não obstante, mesmo com tantas políticas inclusivas em Educação Financeira, o sistema financeiro se torna a cada dia mais complexo e também sofisticado, dificultando a elaboração de um adequado planejamento financeiro. Os consumidores precisam tomar, no dia a dia, inúmeras decisões financeiras, como administrar cartões de crédito, investimentos, seguro, aposentadoria, habitação, entre outros. Muitos demonstram não estar preparados e não 
ter conhecimento para isso. Em uma pesquisa realizada pelo Instituto Data Popular em 2018, verificou-se que aproximadamente $80 \%$ dos consumidores brasileiros não tinham conhecimento da taxa de juros.

Por meio da ENEF, a Educação Financeira começou a ser tratada como tema transversal, na grade curricular dos alunos, assumindo 72 situações didáticas nas disciplinas de matemática, português, ciências, geografia, história e outros. Vale ressaltar ainda que os marcos legais que embasaram a BNCC, no artigo 26 da LDB determinam que

Os currículos da Educação Infantil, do Ensino Fundamental e do Ensino Médio devem ter base nacional comum, a ser complementada, em cada sistema de ensino e em cada estabelecimento escolar, por uma parte diversificada, exigida pelas características regionais e locais da sociedade, da cultura, da economia e dos educandos (BRASIL, 2018, p. 13).

A inclusão dos programas de Educação Financeira nas escolas possibilitou um salto na melhoria do conhecimento, das atitudes e dos comportamentos em relação à forma de lidar com o dinheiro.

Nesta perspectiva, esta pesquisa propõe-se uma prática pedagógica integrada com o Aplicativo Jogo Bolsa de Valores, visando uma experimentação única que tenciona o senso de autonomia e tomada de decisão dos estudantes em problemas contextualizados, promovendo o conhecimento em economia, geopolítica e matemática financeira.

\section{Procedimentos metodológicos e contexto da pesquisa}

Este artigo apresenta um estudo de campo com 40 estudantes de duas turmas do $2^{\circ}$ ano do Ensino Médio do Colégio Estadual Dr. Félix Miranda, situado na cidade de Campos dos Goytacazes no Estado do Rio de Janeiro. Esta pesquisa se baseia em um jogo competitivo entre nove equipes compostas por 4 ou 5 estudantes cada, com o propósito de instigar o conhecimento e as ações sobre investimentos e aplicações financeiras, utilizando um aplicativo denominado Jogo Bolsa de Valores.

De acordo com o Plano Diretor da ENEF (BRASIL, 2017), a Educação Financeira é

O processo mediante o qual os indivíduos e as sociedades melhoram sua compreensão em relação aos conceitos e produtos financeiros, de maneira que, com informação, formação e orientação, possam desenvolver os valores e as competências necessários para se tornarem mais conscientes das oportunidades e dos riscos nele envolvidos e, então, poderem fazer escolhas bem informadas, saber onde procurar ajuda, adotar outras ações que melhorem o seu bem-estar. Assim, podem contribuir de modo mais 
consciente para a formação de indivíduos e sociedades responsáveis comprometidos com o futuro (BRASIL, 2017, p. 20).

A pesquisa utilizou ferramentas quantitativas, no que concerne à quantificação dos resultados e qualitativas de coleta de dados, está enraizada em uma posição epistemológica que reconhece a importância de localizar a pesquisa dentro de um contexto social. Para levantamento dos dados dois questionários investigativos foram elaborados: o primeiro, antes da atividade, para analisar o nível de conhecimento em assuntos relacionados à Educação Financeira; o segundo, aplicado ao final das atividades, avaliando o conhecimento obtido; a opinião dos pesquisados sobre o material didático utilizado, bem como a metodologia adotada.

As atividades ocorreram após a coleta de dados. Antes da aplicação do jogo, é necessário realizar uma preparação mais específica dos estudantes em relação a conhecimentos básicos da Bolsa de Valores, sendo necessário este estudo para a obtenção de resultados mais eficientes. A Tabela 1 apresenta as ações da pesquisa com datas e descrição.

Tabela 1 - Ações da Pesquisa.

\begin{tabular}{|c|c|c|l|}
\hline $\begin{array}{c}\text { Ações da } \\
\text { Pesquisa }\end{array}$ & Data & $\begin{array}{c}\text { Aulas } \\
\text { (50min) }\end{array}$ & \multicolumn{1}{c|}{ Descrição } \\
\hline $\begin{array}{c}\text { Questionário } \\
\text { Investigativo } \\
\text { Inicial }\end{array}$ & $19 / 03 / 2019$ & 2 & $\begin{array}{l}\text { Questionário sobre a temática da pesquisa para analisar o } \\
\text { nível de conhecimento dos estudantes antes das atividades }\end{array}$ \\
\hline Atividade 1 & $28 / 03 / 2019$ & 2 & $\begin{array}{l}\text { Aula expositiva dialogada sobre investimentos e } \\
\text { aplicações pautadas nos textos do Livro Educação } \\
\text { Financeira nas Escolas (BRASIL, 2014, p.142-152) }\end{array}$ \\
\hline Atividade 2 & $03 / 04 / 2019$ & 2 & $\begin{array}{l}\text { Explicação sobre a dinâmica dos investimentos } \\
\text { financeiros. Explicação sobre o tutorial de como utilizar o } \\
\text { aplicativo Jogo Bolsa de Valores (BONEAPPS, 2019) }\end{array}$ \\
\hline Atividade 3 & $04 / 04 / 2019$ & 2 & $\begin{array}{l}\text { Aplicação da prática da atividade com o auxílio do } \\
\text { aplicativo Jogo Bolsa de Valores (BONEAPPS, 2019) }\end{array}$ \\
\hline $\begin{array}{c}\text { Questionário } \\
\text { Investigativo } \\
\text { Final }\end{array}$ & $05 / 04 / 2019$ & 2 & $\begin{array}{l}\text { Questionário final sobre as opiniões dos estudantes em } \\
\text { relação ao trabalho desenvolvido ao longo da pesquisa, a } \\
\text { importância da Educação Financeira, o material didático } \\
\text { utilizado e mensurar o nível de aprendizado gerado pelas } \\
\text { atividades propostas. }\end{array}$ \\
\hline
\end{tabular}

Fonte: Os autores.

Como a utilização do Aplicativo Jogo Bolsa de Valores (Atividade 3) é o cerne da experimentação, alinhamos a pesquisa no formato do tipo Pesquisa-Ação, pois conjecturamos ser apropriado em vistas às características desse tipo de pesquisa. Para Chizzotti (2018, p. 54), a Pesquisa-Ação tem a seguinte definição: "Pesquisa-ação se propõe a uma ação deliberada visando uma mudança no mundo real, comprometida com um campo restrito, englobando em um projeto mais geral e submetendo-se a uma disciplina para alcançar os efeitos do conhecimento". 
As descrições específicas das atividades utilizadas na experimentação foram:

Questionários Investigativos - Nesta pesquisa optou-se por uma estrutura de questionamento com perguntas fechadas, permitindo que essas se encaixem em categorias pré-decididas. Nesse sentido, para a prática da pesquisa de ação participativa, foram elaborados dois questionários investigativos denominados por Questionário Investigativo Inicial (Tabela 2), aplicado antes da experimentação e Questionário Investigativo Final (Tabela 3) aplicado ao término da experimentação.

Tabela 2 - Detalhes do Questionário Investigativo Inicial.

\begin{tabular}{|c|c|}
\hline Questionamento & Opções de respostas \\
\hline $\begin{array}{l}1 \text { - Você se sente seguro para efetuar cálculos } \\
\text { envolvendo matemática financeira? }\end{array}$ & $\begin{array}{l}\text { ( ) Sim; } \\
\text { ( ) Mais ou menos; } \\
\text { ( ) Não; }\end{array}$ \\
\hline $\begin{array}{l}2 \text { - Na sua opinião, o conhecimento matemático pode } \\
\text { ajudar a lidar melhor com o dinheiro? }\end{array}$ & $\begin{array}{l}\text { ( ) Sim; } \\
\text { ( ) Mais ou menos; } \\
\text { ( ) Não; }\end{array}$ \\
\hline $\begin{array}{l}3 \text { - Qual o grau de importância que você atribui à } \\
\text { Educação Financeira nas escolas? }\end{array}$ & $\begin{array}{l}\text { ( ) Indispensável; } \\
\text { ( ) Importante; } \\
\text { ( ) Pouco importante; }\end{array}$ \\
\hline 4 - Como você organiza seus gastos? & $\begin{array}{l}\text { ( ) Não organizo; } \\
\text { ( ) Não organizo, pois tenho acesso a valores } \\
\text { financeiros muito baixos; } \\
\text { ( ) Me organizo somente para os gastos mais } \\
\text { altos; } \\
\text { ( ) Registro em planilhas todos os meus gastos } \\
\text { mensais; } \\
\text { ( ) Outros: }\end{array}$ \\
\hline $\begin{array}{l}5 \text { - Você conhece a dinâmica da Bolsa de Valores de } \\
\text { São Paulo [B3]? }\end{array}$ & $\begin{array}{l}\text { ( ) Sim; } \\
\text { ( ) Mais ou menos; } \\
\text { ( ) Não; }\end{array}$ \\
\hline $\begin{array}{l}6 \text { - Se você tivesse dinheiro para investir, em qual das } \\
\text { alternativas adiante você investiria? }\end{array}$ & $\begin{array}{l}\text { ( ) Deixaria guardado e não investiria, pois } \\
\text { desconheço qualquer tipo de investimento; } \\
\text { ( ) Investiria em bens (casa, carro, } \\
\text { apartamento,...) } \\
\text { ( ) Investiria em ações, pela possibilidade de altos } \\
\text { ganhos, mesmo sabendo do risco elevado de } \\
\text { perdas; } \\
\text { ( ) Investiria em renda fixa de risco médio, porém } \\
\text { com retornos acima da inflação; } \\
\text { ( ) Investiria em título do governo, como títulos } \\
\text { do Tesouro, mesmo com possíveis turbulências } \\
\text { governamentais e/ou crise instalada no país; } \\
\text { ( ) Investiria em poupança, mesmo rendendo a } \\
\text { mesma taxa de inflação, pois priorizo a segurança } \\
\text { em relação ao meu dinheiro. }\end{array}$ \\
\hline 7 - Resolução de Problema: & $\begin{array}{l}\text { Suponha-se que você tenha um capital } \mathrm{R} \$ 2.000,00 \\
\text { e pretende investir seu dinheiro numa Renda Fixa } \\
\text { que rende } 12 \% \text { ao ano, pergunta-se: ao final de } 30 \\
\text { meses qual será o valor do seu capital? }\end{array}$ \\
\hline
\end{tabular}


Tabela 3 - Detalhes do Questionário Investigativo Final.

\begin{tabular}{|l|l|}
\hline \multicolumn{1}{|c|}{ Questionamento } & \multicolumn{1}{c|}{ Opções de respostas } \\
\hline $\begin{array}{l}\text { 1- Após a realização desse experimento, você se } \\
\text { sente mais capaz de lidar com assuntos financeiros, } \\
\text { em especial investimentos? }\end{array}$ & $\begin{array}{l}\text { ( ) Sim; } \\
\text { ( ) Mais ou menos; } \\
\text { ( ) Não; }\end{array}$ \\
\hline $\begin{array}{l}2 \text { - Você acredita que se a Educação Financeira } \\
\text { fosse abordada com maior ênfase no ambiente } \\
\text { escolar as pessoas teriam posturas mais conscientes } \\
\text { em relação à gestão do dinheiro? }\end{array}$ & $\begin{array}{l}\text { ( ) Sim; } \\
\text { ( ) Não; }\end{array}$ \\
\hline $\begin{array}{l}\text { 3- Em relação às atividades propostas } \\
\text { envolvendo: juros, investimentos, empréstimos, } \\
\text { cálculos, reforçado com situações problema no } \\
\text { mercado de ações, foi significativo para a sua } \\
\text { aprendizagem? }\end{array}$ & $\begin{array}{l}\text { ( ) Sim; } \\
\text { ( ) Não; } \\
\text { Justifique: }\end{array}$ \\
\hline $\begin{array}{l}\text { un - Como você classifica os vídeos e materiais } \\
\text { utilizados nesta experimentação? }\end{array}$ & $\begin{array}{l}\text { ( ) Muito atrativos; } \\
\text { ( ) Medianos; }\end{array}$ \\
\hline $\begin{array}{l}\text { ( ) Pouco atrativos; } \\
5 \text { - Resolução de Problema: }\end{array}$ & $\begin{array}{l}\text { Supondo um rendimento de } 0,5 \% \text { ao mês aplicado } \\
\text { na caderneta de poupança, quanto terá um } \\
\text { investidor ao aplicar R } \$ 2.000,00 \text { por } 2 \text { meses? }\end{array}$ \\
\hline
\end{tabular}

Fonte: Os autores.

Atividade 1 - É baseada nas seguintes descrições específicas: (1) - Aula expositiva dialogada sobre investimentos e aplicações com análises e discussões pautadas nos textos do Livro Educação Financeira nas Escolas (BRASIL, 2014, p. 142-152); (2) - Solicitação aos estudantes que possuíam aparelhos celulares realizassem o download do aplicativo Jogo Bolsa de Valores. Nesta atividade é importante discutir com os estudantes a diferença entre renda fixa e renda variável, apontando seus pontos fortes e fragilidades para cada tipo de investimento.

Atividade 2 - A descrição específica dessa atividade está voltada para o entendimento sobre a dinâmica dos investimentos financeiros (renda fixa e renda variada) e como utilizar o aplicativo Jogo Bolsa de Valores. Nesta atividade, os discentes devem assistir aos vídeos listados a seguir, com discussões posteriores. Os vídeos explicam, de forma clara e sucinta, a dinâmica do mercado financeiro, e foram escolhidos nesta pesquisa pela forma prática e didática, se adequando ao perfil dos pesquisados. Os vídeos são listados a seguir: Vídeo (1) O que é a Bolsa de Valores? (TORO, 2018b); O Vídeo (1) (Figura 1) apresenta a dinâmica da Bolsa de Valores, através de dados estatísticos consistentes. Também são apresentadas as principais empresas envolvidas na Bolsa de Valores de São Paulo [B3], além de discutir sobre 
o mercado secundário, oportunidades, inserção na Bolsa de Valores, entre outros. O Vídeo (2)

- Como investir na Bolsa de Valores? (TORO, 2018a); O Vídeo (2) (Figura 2) apresenta passos importantes para efetivação na Bolsa de Valores. Ainda neste vídeo é enfatizada a importância de investir no momento certo e a importância da escolha da ação a ser comprada. Além dos procedimentos burocráticos para compra e venda de ação, é discutido sucintamente sobre planejamentos como análise de dados, gerenciamento de risco, entre outras.

Figura 1 - Tela principal do Vídeo (1) - O que á a Bolsa de Valores.

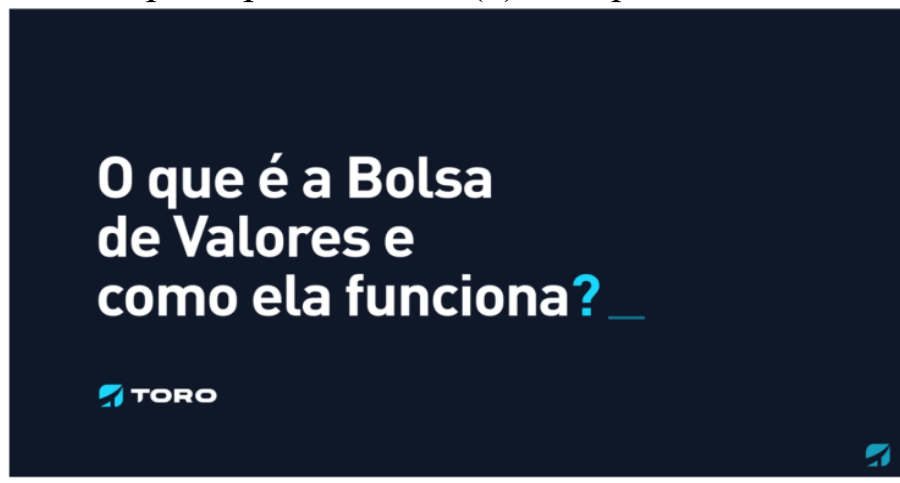

o que é Bolsa de Valores? |A Toro Investimentos explica

Fonte: (TORO, 2018b).

Figura 2 - Tela secundária do Vídeo (2) - Como investir na Bolsa de Valores?
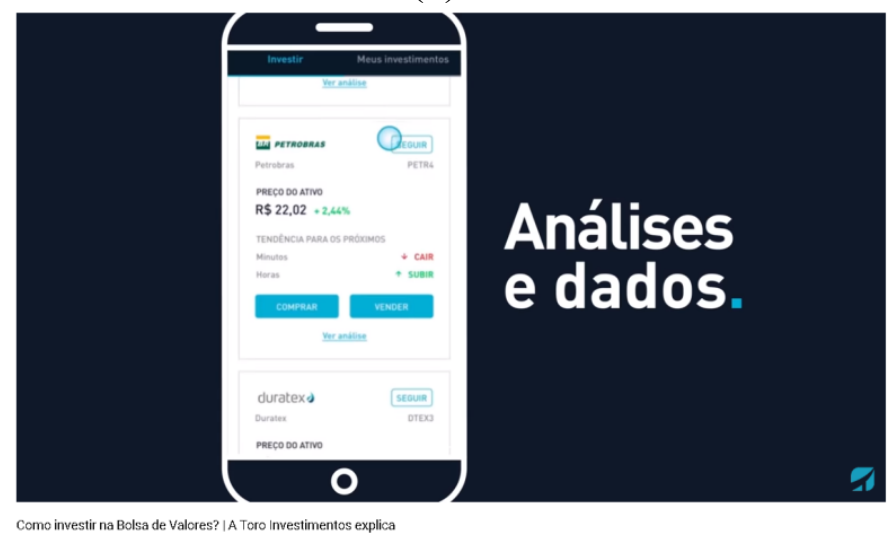

Fonte: (TORO, 2018a).

O Vídeo (3) - O que são Commodities e como investir? (EU QUERO INVESTIR, 2018) (Figura 3) apresenta de forma sucinta a definição de Commodities, destacando os mais produzidos no Brasil, como o café, soja e o minério de ferro. O vídeo traz exemplos de aplicações interessantíssimos e didáticos sobre esse tipo de mercado. 
Figura 3 - Tela principal do Vídeo (3) - O que são Commodities e como investir?

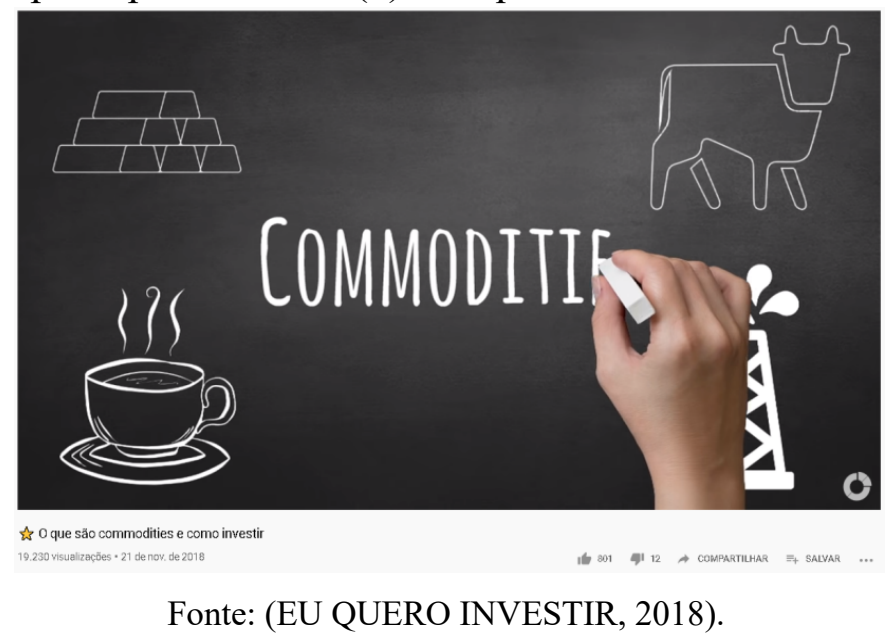

Atividade 3 - A descrição específica dessa atividade foi aplicação do jogo, com o auxílio do aplicativo Jogo Bolsa de Valores (BONEAPPS, 2019). Estimulados pela competição, nessa atividade, os integrantes tomarão decisões diante de situações de aplicação financeira, simuladas pelo aplicativo.

No aplicativo Jogo Bolsa de Valores, os estudantes poderão aprender aspectos importantes sobre Matemática Financeira, economia e até mesmo entendimentos mais avançados sobre a dinâmica da Bolsa de Valores. Os alunos poderão aprender a fazer investimentos, ganhar ou perder dinheiro com as cotações, tendo a oportunidade de analisar seus riscos em cada decisão, jogando com uma estratégia baseada em análise gráfica, cálculos matemáticos e tomada de decisão. O aplicativo é simples, gratuito, sem cadastro e contas de demonstração. É um jogo que simula de forma real a dinâmica da Bolsa de Valores. O aplicativo Jogo Bolsa de Valores é o único no mundo com estratégia sobre economia, baseado em milhares de eventos mundiais. Os usuários ficarão informados sobre notícias geopolíticas e econômicas que poderão impactar positivamente ou negativamente os preços das cotações. Em vez de adivinhar, o estudante poderá estimar o percurso dos preços baseado apenas em suas próprias estratégias. Milhões de combinações complexas tornam cada passo do jogo único e diferente. No aplicativo Jogo Bolsa de Valores é utilizado um sistema único de gestão e treinamento que permite maximizar a utilização dos seus conhecimentos e habilidades. É um jogo no qual o usuário se desenvolve a cada rodada, podendo treinar a atenção, conceitos matemáticos, a memória e a mente analítica.

Além de tudo, este jogo promove a desenvoltura e a coragem dos estudantes a negociar futuramente na Bolsa de Valores. O Jogo revela as informações sobre finanças e investimentos e prepara os estudantes para o negócio real no mercado Forex. Jogabilidade 
única, baseada no complexo modelo econômico mundial; Originalidade e a diversidade a cada interação.

A Figura 4 mostra a imagem principal ao acessar o site do aplicativo.

Figura 4 - Tela principal do aplicativo Jogo Bolsa de Valores.
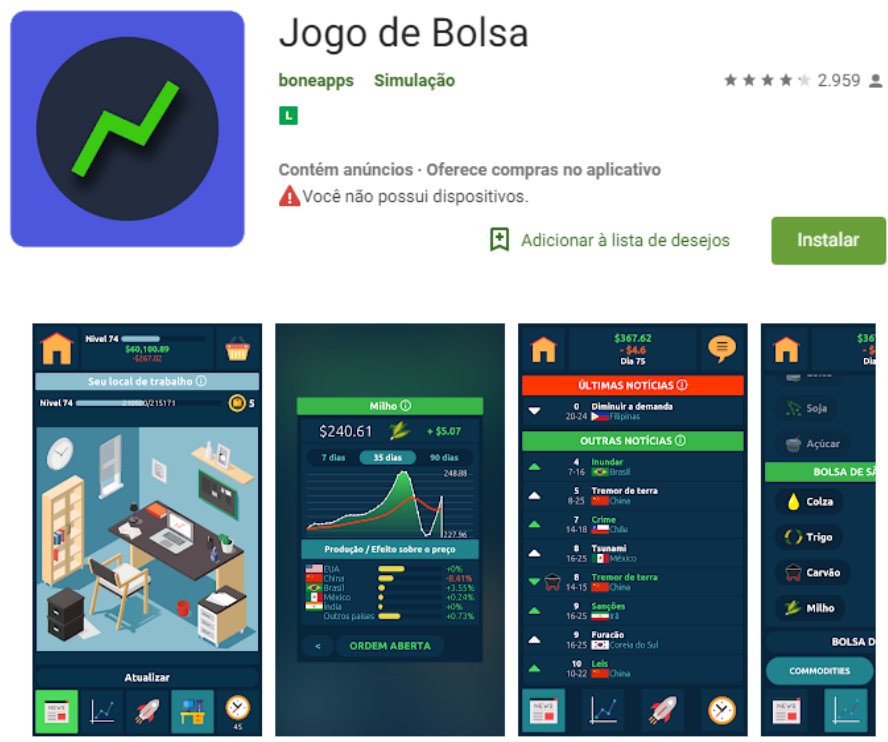

Fonte: (BONEAPPS, 2019).

Em resumo, o Jogo Bolsa de Valores simula investimentos na Bolsa de Valores por meio de estratégias financeiras. O aplicativo está disponível para download no site (BONEAPPS, 2019). As Regras do jogo propostas nesta pesquisa são: (1) - Cada equipe deve ser composta por 3 a 5 integrantes. (2) - Cada equipe deve eleger um líder, o qual terá a incumbência de decidir as ações, caso haja discordância entre os integrantes; (3) - A cada 5 turnos, o que deve ocorrer em no máximo 2 minutos e 30 segundos, o saldo de cada equipe é registrado, com a verificação do aplicador, e exposto para a ciência de todos os participantes em uma planilha eletrônica; (4) - A disputa é finalizada no $50^{\circ}$ turno. A equipe com maior saldo será declarada a vencedora.

O jogo se baseia na compra e venda de mercadorias, simulando as transações com commodities. Todas as equipes iniciam o jogo com um saldo de 1000 unidades monetárias e devem investir o valor disponível em produtos que tragam maior ganho ou menor perda possível. Há ainda uma seção de notícias de impacto global que influencia no aumento ou na perda de valores das mercadorias comercializadas, como mostra a Figura 5, por exemplo. Essas notícias são importantes para a tomada de decisão dos estudantes nas próximas etapas do jogo. Após a sua tomada de decisão sobre como investir (compra ou venda), sendo esta baseada em eventos geopolíticos e econômicos, o jogador deve mudar de turno (decorrência 
do tempo) e analisar as possíveis perdas ou ganhos. Todo o ambiente do jogo é planejado para uma imersão do jogador em situações da realidade.

Figura 5 - Notícias aleatórias geradas pelo aplicativo.

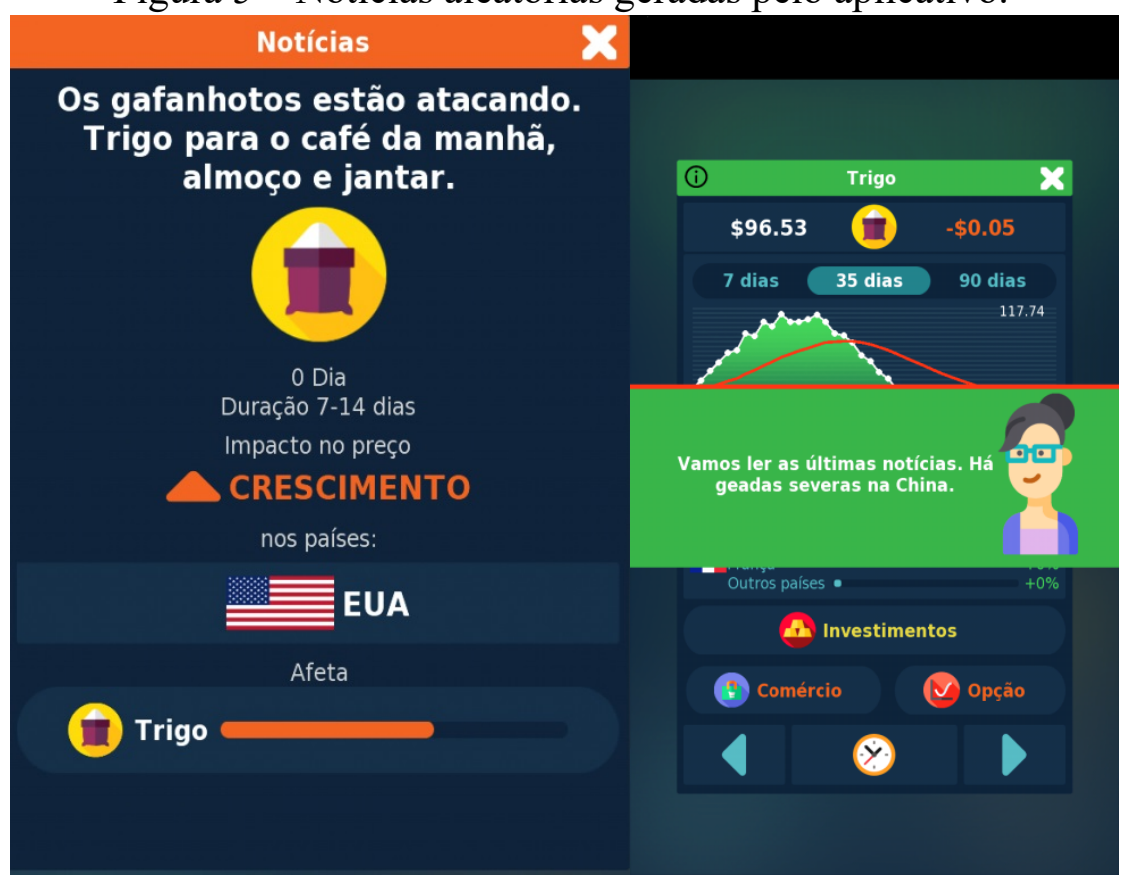

Fonte: (BONEAPPS, 2019).

O jogo conta com seções onde é possível analisar gráficos de perdas e ganhos. Ao abrir uma ordem (aplicação do dinheiro) é exposto para o jogador o preço, quantidade, taxa por abertura e taxa por dia (turno) e o preço total do investimento, como mostra a Figura 6.

Existe ainda a possibilidade de realizar empréstimos e melhorar a estrutura do "local de trabalho" (Figura 7), o que pode trazer mais ganhos devido às condições favoráveis de trabalho. A opção de empréstimo é uma excelente oportunidade para explorar tópicos relacionados à Educação Financeira. 
Figura 6 - Ordem de compra ou venda do trigo utilizado pelo jogador.

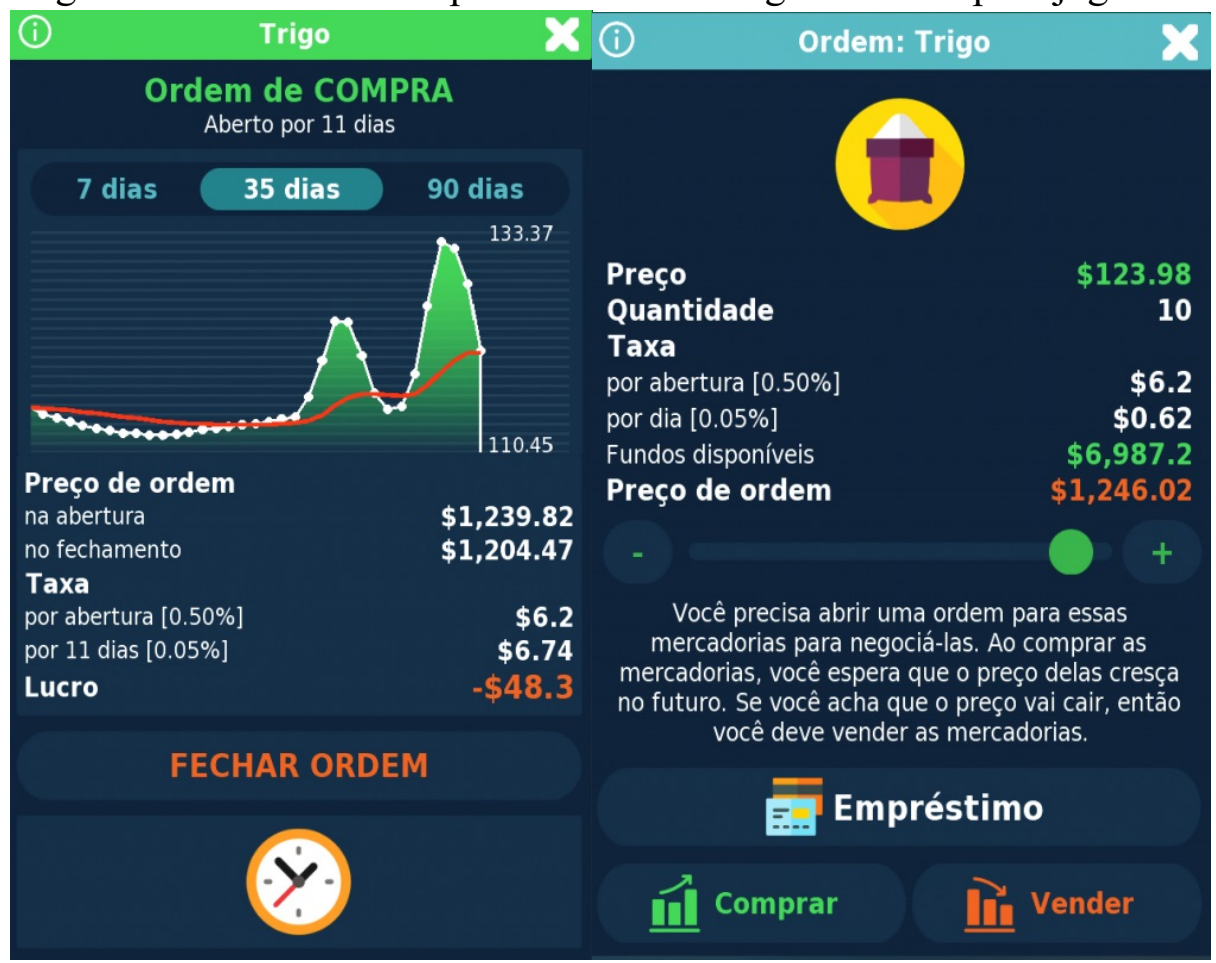

Fonte: (BONEAPPS, 2019).

Figura 7 - Ordem de empréstimo (à esquerda) e informações para atualização do local de trabalho (à direita)

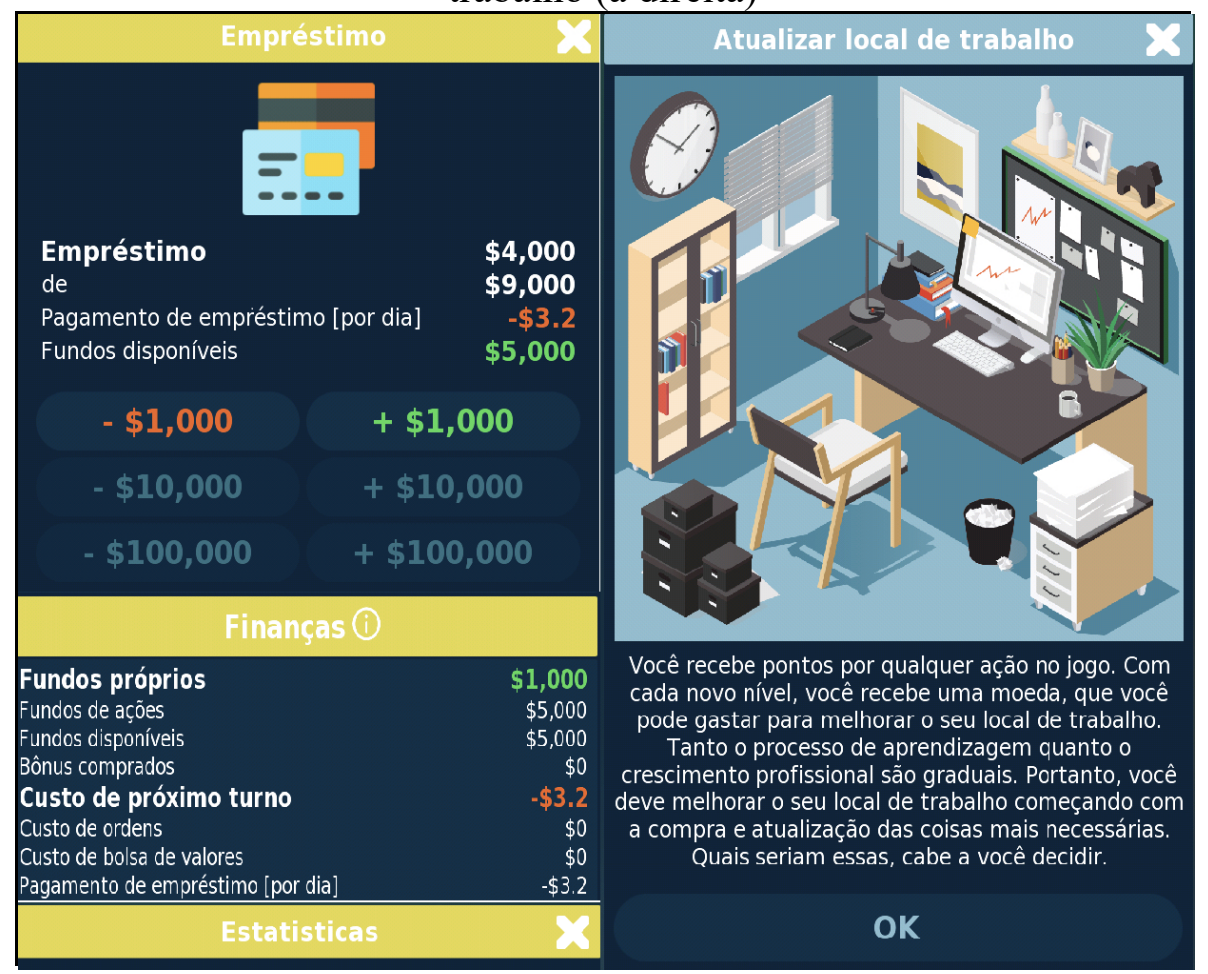

Fonte: (BONEAPPS, 2019). 
Por fim, os estudantes serão avaliados através das observações e registros mediante o exposto nos questionários (Tabela 2 e 3). A avaliação pretende verificar se a integração do aplicativo Jogo Bolsa de Valores na experimentação contribuiu para o desenvolvimento cognitivo dos pesquisados frente aos conceitos iniciais da Educação Financeira, em especial, investimentos em renda variável.

\section{Desenvolvimento e resultados da pesquisa}

Neste artigo serão abordados alguns questionamentos de maior relevância na pesquisa. Serão apresentados alguns dados quantitativos referentes aos questionários investigativos e alguns dados qualitativos referentes às observações dos pesquisadores e registros dos próprios pesquisados.

A primeira pergunta do questionário investigativo inicial foi elaborada a fim de averiguar a segurança dos pesquisados quanto aos cálculos envolvendo conceitos de matemática financeira. Das 40 respostas, 72,5\% apresentaram insegurança na utilização de tais conceitos. Quando questionados sobre a importância de conteúdos de matemática para auxiliarem nas questões financeiras, todos os pesquisados responderam positivamente.

Em seguida, os estudantes foram questionados sobre o conhecimento da dinâmica da Bolsa de Valores de São Paulo [B3], e como era esperado nesta pesquisa, todos os pesquisados informaram não terem quaisquer conhecimentos sobre as características da Bolsa de Valores. Os dados do Brasil Escola (BRASIL ESCOLA, 2020) corroboram estes resultados quando afirmam que "A grande maioria das pessoas técnicos ou não, de todas as classes sociais no Brasil desconhecem o objetivo e o funcionamento da Bolsa de Valores". Essa afirmação reflete nas escolas brasileiras, onde muito pouco é discutido esse tipo de investimento.

E quando falamos de investimento, sabe-se que esta ação pode garantir bem-estar financeiro a curto e longo prazo, sendo um dos pilares principais da Educação Financeira. $\mathrm{O}$ dinheiro gerado a partir dos investimentos pode proporcionar segurança financeira e renda. Quando questionados sobre a forma como deveriam proceder de posse de valores financeiros, boa parte dos estudantes demonstrou um desconhecimento nesse quesito, como mostra a Figura 8. 
Figura 8 - Questionário Investigativo inicial: "Em qual das alternativas abaixo você investiria?"

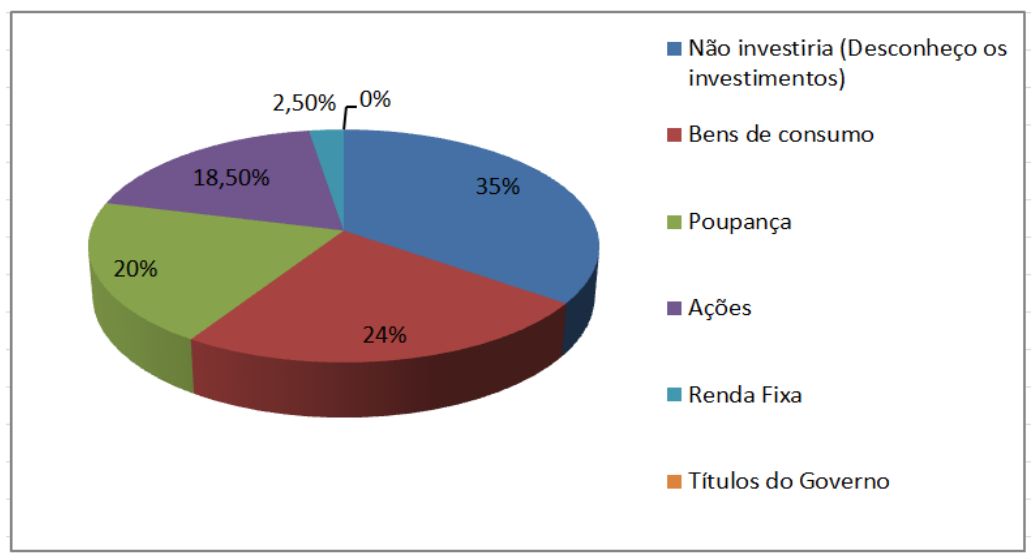

Fonte: Dados da pesquisa.

Observa-se na Figura 8 que $35 \%$ dos estudantes desconhecem qualquer tipo de investimento, mesmo o investimento mais popular no Brasil, a Poupança.

Por consequência, este questionário inicial além de cumprir os objetivos iniciais propostos, externou-se um excelente espaço para gerar discussões e reflexões com os estudantes sobre a Educação Financeira, em especial os tipos de investimentos mais usuais como Ações, Renda Fixa e Títulos do Tesouro, os quais serão discutidos nas Atividades 1 e 2. Também se apresentou um excelente ambiente para discutir sobre a Matemática Financeira por detrás desses tipos de investimentos. Falar sobre a Matemática Financeira envolvida na dinâmica dos investimentos foi algo eficaz nesta pesquisa, pois "acendeu a chama" do interesse dos estudantes sobre a Matemática e assuntos monetários.

As Atividades 1 e 2 tiveram como foco a explicação de conceitos que seriam utilizados na Atividade 3. Na Atividade 1 utilizou-se o Livro Educação Financeira nas Escolas (BRASIL, 2014, p. 142-152), no qual foram explorados exemplos práticos de aplicações em investimentos, sendo necessária a utilização da matemática financeira visando melhores decisões. Após a observação e análise dos registros dos estudantes a respeito destas atividades, chegou-se às seguintes constatações:

- Os estudantes aprenderam sobre finanças pessoais. Discussões do tipo: "gaste menos do que você ganha", "como controlar suas finanças", "os melhores tipos de investimentos", foram debatidas amplamente, gerando reflexões interessantíssimas do ponto de vista positivo da Educação Financeira, como por exemplo, "poupar para investir"; 
- Embora a maioria dos alunos tenha demonstrado dificuldades na resolução de problemas que envolvem a Matemática Financeira, todos os pesquisados se mostraram motivados nas aplicações matemáticas envolvidas nas exemplificações das atividades;

- Os estudantes aprenderam a diferenciar os tipos de investimentos: Renda Fixa (Poupança, Certificado de Depósito Bancário - CDB, Títulos do Tesouro) e Renda Variável (Bolsa de Valores) e os riscos nelas presentes;

- Os pesquisados compreenderam de forma satisfatória a dinâmica da Bolsa de Valores de São Paulo [B3] e como investir nela. Era comum comentários do tipo: "Nossa!!!Achei que era mais complicado."; "Muito legal, porém é arriscado!!"; "Nem imaginava que a matemática era tão importante na Bolsa de Valores"; entre outros.

- Por fim, os pesquisados entenderam a definição de Commodities e aprenderam a parte burocrática de como investir nesse ramo.

A partir destas constatações, foi aplicada atividade cerne da experimentação, Atividade 3. Essa é uma atividade para ensinar uma simulação sobre mercado de ações, baseado em decisões matemáticas e econômicas baseadas em Matemática Financeira básica. Nenhum conhecimento avançado sobre o mercado de ações é necessário para a realização desta atividade. Apropriado para todos os graus de escolaridade, deve-se enfatizar que a atividade pode ser adaptada para diversas faixas etárias. O tempo envolvido é relativo, dependendo do nível de idade dos estudantes e da necessidade ou não de aprofundamento, podendo variar de 2 a 6 aulas.

Será utilizado nesta atividade o aplicativo Jogo Bolsa de Valores. Este jogo faz simulações típicas do mercado de ações, criando um ambiente de "competição", sendo considerado vencedor aquele que conseguir o maior sucesso financeiro. Diferentemente das simulações típicas do mercado de ações, o objetivo aqui é aprender e compreender princípios básicos de investimento; eventos atuais; noções básicas do funcionamento da economia; habilidades de gerenciamento de dinheiro; aplicação da Matemática Financeira, Estatística Básica e compreensão de leitura e tomada de decisão, além de habilidades na escrita, entre outros.

Em relação à utilização de jogos na aprendizagem, Rodrigues e Ricci (2008, apud BIANCHINI; GERHARDT; DULLIUS, 2010, p. 3) afirmam que “[...] jogar não é estudar, nem trabalhar, porque jogando o aluno aprende, sobretudo, a conhecer e compreender o 
mundo social que o rodeia". A Figura 9 mostra os estudantes reunidos e concentrados no aplicativo, apresentando forte interesse e interação entre eles.

Figura 9 - Interação dos estudantes no início da atividade.

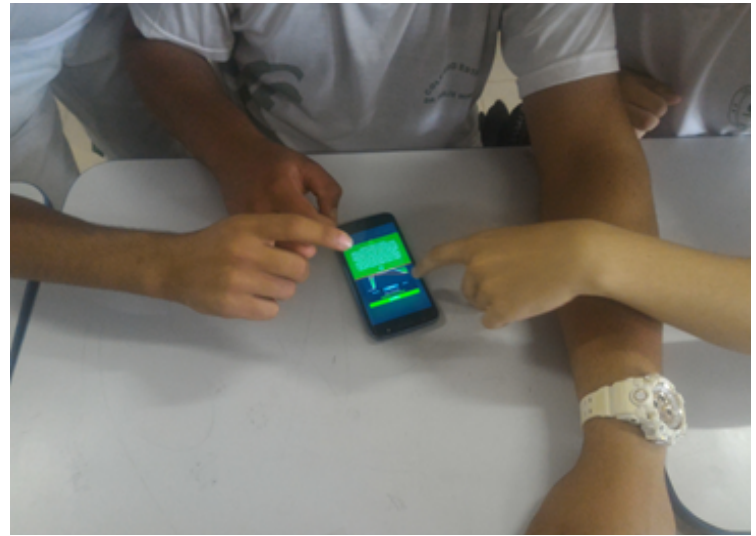

Fonte: Dados da pesquisa.

Durante a execução da atividade, foram observadas várias situações que merecem ser relatadas, pois ilustram a importância de promover a reflexão dos estudantes sobre as questões de investimentos e tomada de decisão. Adiante são apresentadas algumas das reproduções relevantes dos dados coletados neste experimento.

"Devíamos ter aumentado nosso aporte nessa rodada...com mais $R \$ 100,00$ teríamos lucrado quase 20\% a mais!” (Equipe A).

"Nossa!! Arriscamos e nos demos mal... a geada nos EUA acabou nos prejudicando nessa rodada. Não tínhamos que ter comprado.” (Equipe B).

As falas dos Grupos A e B foram alguns exemplos de reflexões baseadas em análises e tomadas de decisões, mediante as circunstâncias gerados pelo Jogo. As Equipes tinham total autonomia de como fazer seus investimentos (aportes), alguns deles criaram soluções interessantíssimas, como relata a Equipe E.

"As notícias são boas!! A China vai importar mais soja do Brasil nesse semestre...vamos pegar um empréstimo e fazer um aporte maior." (Equipe E).

Embora a ideia da Equipe E seja viável, a mesma é muito arriscada. Infelizmente os juros obtidos pelo empréstimo não superaram a expectativa dos integrantes do grupo no aumento da cotação da soja, obtendo retornos negativos nessa operação. Vale ressaltar que os estudantes da Equipe E calcularam os juros antes de fazer seus aportes, tendo conhecimento 
dos riscos da operação. Entretanto muitas Equipes apresentaram criatividade, autonomia e perspicácia nas tomadas de decisão, como apresenta a fala da Equipe G por exemplo.

"Vendemos na hora certa, com lucro de 30\%... vamos aproveitar o término da geada e comprar mais." (Equipe G).

Após 50 rodadas o jogo é finalizado e os dados computados. A Figura 10 mostra o ranking parcial que foi realizado durante as atividades, com a vitória da Equipe G. Outro aspecto positivo nesta atividade está no fato da sensibilização nos estudantes neste tipo de investimento, conhecido como investimento de renda variável, podendo dar retornos negativos, como foi o caso das Equipes E e B.

Figura 10 - Ranking parcial da Atividade 3

\begin{tabular}{|c|c|c|c|c|c|c|c|c|c|c|}
\hline Equipe & 50 turno & 109 turno & $15 \%$ turno & 209 turno & 259 turno & 30 turno & $35 \%$ turno & 409 turno & $45 \%$ turno & 50 turno \\
\hline A & 77,88 & 982,44 & 1059,13 & 1058,47 & 1047,29 & 1042,11 & 1074,01 & 1099,83 & 1103,97 & 1072,14 \\
\hline B & 994,67 & 971,26 & 965,6 & 955,93 & 929,92 & 883,56 & 861,61 & 837,03 & 787,33 & 723,31 \\
\hline C & 1098,69 & 1063,45 & 899,29 & 899,24 & 922,62 & 308,52 & 887,66 & 1125,81 & 1121,82 & 1117,81 \\
\hline D & 140,77 & 1091,17 & 1070,4 & 1095,58 & 1096,53 & 1081,81 & 1066,07 & 1086,05 & 1091,74 & 1098,66 \\
\hline E & 1025,42 & 439,14 & 945,21 & 935,95 & 953,34 & 987,97 & 996,17 & 995,15 & 970,5 & 969,12 \\
\hline $\mathrm{F}$ & 1048,93 & 1044,95 & 985,94 & 1026,59 & 1055,08 & 1076,98 & 1036,59 & 1030,94 & 1016,96 & 1007,27 \\
\hline G & 1009,24 & 941,83 & 1264,3 & 1318,21 & 1451,93 & 1421,85 & 1422,28 & 1399,6 & 1393,98 & 1392,95 \\
\hline $\mathrm{H}$ & 65 & 1029,5 & 1207,84 & 1210,69 & 1247,8 & 1265,78 & 1252,83 & 1263,15 & 1267,3 & 1256,08 \\
\hline & 1086,99 & 1069,37 & 1100,26 & 1040,94 & 1179,97 & 1185,3 & 1192,63 & 1205,71 & 1227,1 & 1216,01 \\
\hline
\end{tabular}

Fonte: Dados da pesquisa.

A Figura 10 apresenta dados muito interessantes. As Equipes A e H, por exemplo, começaram o jogo com riscos e aportes maiores, ignorando as notícias e sem nenhum tipo de estratégia ou planejamento, obtendo perdas iniciais de $92 \%$ e $93,5 \%$ respectivamente até o $5^{\circ}$ turno. Entretanto, apresentaram um amadurecimento considerável no decorrer do jogo, com tomadas de decisões conscientes, baseadas em Matemática Financeira e nos eventos geopolíticos gerados pelo Jogo. Ao final as duas equipes obtiveram saldo positivo, tendo um progresso considerável do $5^{\circ}$ ao $50^{\circ}$ turno, onde obtiveram ganhos de mais de $1300 \%$ e $1900 \%$ respectivamente.

A Equipe B infelizmente por muitas vezes ignorou ou interpretou equivocadamente as notícias que influenciavam diretamente seus investimentos, obtendo uma rentabilidade final de $-27,7 \%$. Por outro lado, a Equipe G aproveitou oportunidades de compra e venda, com pequenos riscos e aportes moderados, apresentando coerência e planejamento em suas decisões, gerando um lucro de quase $40 \%$.

Em geral, a experimentação por meio do jogo foi muito positiva, indo ao encontro do trabalho de Silva (2005, p. 26), que afirma: 
Ensinar por meio de jogo é um caminho para o educador desenvolver aulas mais interessantes, descontraídas e dinâmicas, podendo competir em igualdade de condições com inúmeros recursos a que o aluno tem acesso fora da escola, despertando ou estimulando sua vontade de frequentar com assiduidade a sala de aula e incentivando seu envolvimento nas atividades, sendo agente no processo de ensino e aprendizagem, já que aprende e se diverte, simultaneamente.

Após a realização da Atividade 3, chegou o momento do questionário investigativo final. O objetivo foi obter o feedback dos pesquisados a respeito da experimentação e avaliar seus conhecimentos adquiridos ao final do experimento.

$\mathrm{O}$ primeiro questionamento está relacionado à confiança em lidar com assuntos financeiros, em especial investimentos. A maioria dos pesquisados (63\%) informou estar mais confiante em lidar com investimentos após a pesquisa. Questionados: "se a Educação Financeira fosse abordada com maior ênfase no ambiente escolar, as pessoas teriam posturas mais conscientes, no futuro, em relação à gestão do dinheiro", o resultado foi unânime, ou seja, $100 \%$ dos pesquisados marcaram a opção sim.

Em relação às atividades propostas, todos os estudantes informaram que obtiveram um aprendizado prazeroso e significativo, destacando o aplicativo Jogo Bolsa de Valores como atividade fundamental para aplicar os conceitos vistos no decorrer da experimentação, como afirma o Aluno 1 (Figura 11). Em relação ao material didático trabalhado na pesquisa (Livro base, vídeos, aplicativo e atividades), 88,5\% afirmaram ser muito atrativo e os outros $11,5 \%$ declararam o material mediano.

Figura 11 - Opinião do Aluno 1 referente às atividades da experimentação.

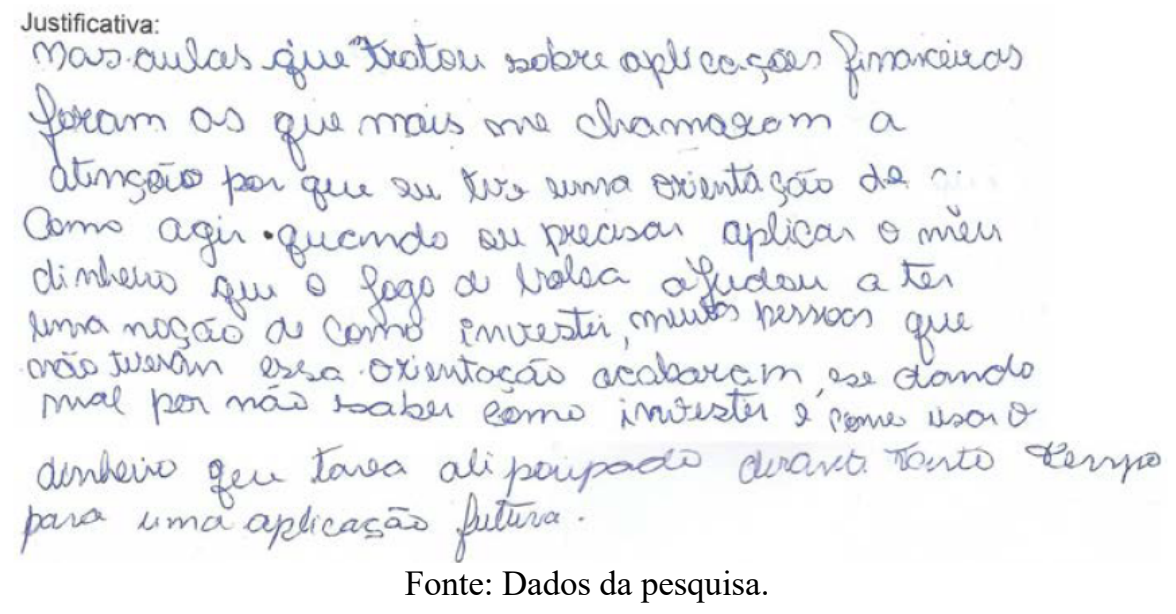

Por fim, a Figura 12 mostra os resultados do problema relacionados à Matemática Financeira (investimento) que apesar de ser tratada, sutilmente, está diretamente ligada aos assuntos trabalhados na experimentação da pesquisa. Deseja-se, com este problema, não 
somente avaliar os conhecimentos obtidos experimentalmente pelos estudantes, mas também promover uma percepção da relação entre a experimentação e a Matemática Financeira que, neste trabalho, não foi protagonista, mas uma ferramenta importante e útil para a difusão da Educação Financeira nas aulas de Matemática, em especial investimentos.

Figura 12 - Questionário Investigativo Final: Resolução de Problema - Investimentos

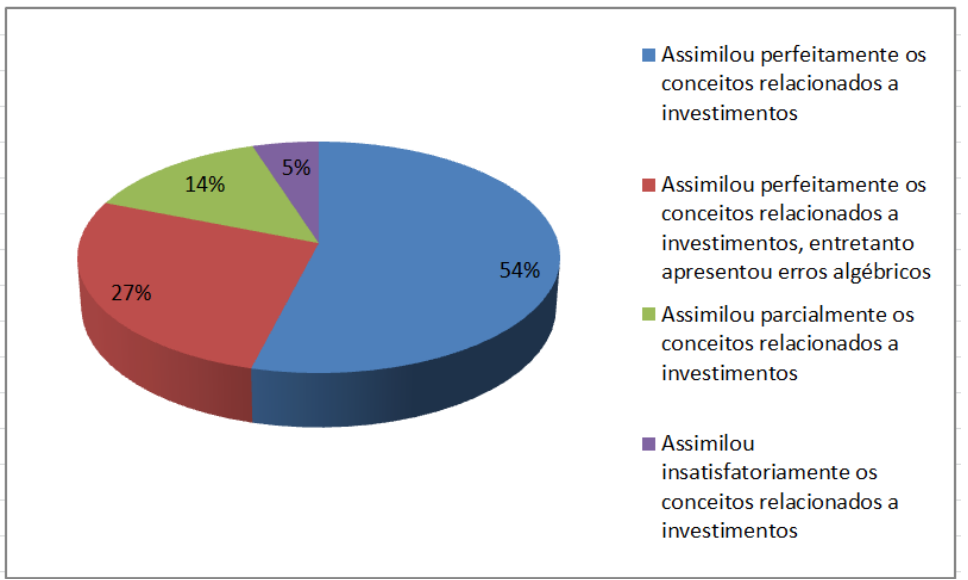

Fonte: Dados da pesquisa.

Os resultados apresentados apontaram para um progresso significativo no entendimento dos estudantes em relação a todas as etapas da pesquisa e à Educação Financeira como um todo, bem como sua aplicação no cotidiano. Pôde-se notar um maior nível de maturidade de todos os envolvidos no processo, na sua forma de se portar e de dialogar sobre a temática.

A análise dos dados levantados, das justificativas, intervenções pedagógicas e dos registros das atividades permitiu confirmar as vantagens da experimentação didática integrada com o aplicativo Jogo Bolsa de Valores. Além disso, foi possível constatar que a sequência didática integrada com a tecnologia juntamente com a intervenção dos pesquisadores contribuíram para a construção do conhecimento sobre os conceitos da Educação Financeira, em especial, investimentos.

\section{Considerações finais}

O presente artigo apresenta-se com o intuito de contribuir, com um olhar pedagógico, de forma a atingir todos os envolvidos no processo educacional. Conjectura-se que este trabalho possa trazer um novo prisma sobre a inserção da Educação Financeira a fim de que as escolas formem cidadãos autocríticos em relação ao uso do dinheiro e à tomada de decisão no que diz respeito às finanças, em especial investimentos. 
Durante as etapas desta pesquisa foi possível perceber a evolução dos envolvidos nos quesitos: tomada de decisão, promoção cognitiva em matemática financeira, conceituação de termos financeiros e conscientização em relação à gestão financeira.

Foi apresentada uma sequência de atividades que abordam os conteúdos de matemática financeira no campo do investimento, sendo esse um dos pilares principais da Educação Financeira. Os estudantes tiveram a oportunidade de participar ativamente da construção do conhecimento utilizando o aplicativo Jogo Bolsa de Valores. O uso do aplicativo foi de fundamental importância, pois possibilitou a interação dos estudantes com assuntos relacionados à economia, facilitando a formalização e conceituação dos conteúdos relacionados à Bolsa de Valores. Além disso, a utilização do aplicativo Jogo Bolsa de Valores trouxe modernidade e interação a uma geração que está completamente alfabetizada tecnologicamente. Durante o uso de tal ferramenta, vivenciou-se, na prática, uma integração entre a tecnologia e a sala de aula. Os resultados foram aulas que interessaram os participantes, aumentando a expectativa de aquisição do conhecimento.

No que se refere ao tema investimento, pôde-se observar um grande interesse dos participantes envolvidos em relação ao assunto. Foram esclarecidas dúvidas conceituais relacionadas a termos usados no mercado financeiro. Houve grande entusiasmo durante o desenvolvimento das atividades; os participantes puderam fazer uso de dispositivos eletrônicos para simular e entender a dinâmica da Bolsa de Valores, o que tornou tal experiência agradável e construtiva.

Futuramente há o desejo de ampliação do objeto de estudo para análise da dinâmica de investimentos, bem como aplicações financeiras menos complexas, como Títulos do Tesouro, Certificado de Depósito Bancário - CDB, entre outros, além de investigar novas formas de ensinar conceitos de Educação Financeira para leigos e ainda estimular uma cultura de investimento na sociedade.

Baseado nas interações, nas participações das atividades propostas e nas resoluções escritas pelos alunos, constata-se que o objetivo geral foi atendido, pois o mesmo foi capaz de desenvolver o senso de autonomia, tomada de decisão e assimilação dos conceitos sobre Educação Financeira. Os estudantes envolvidos na pesquisa puderam compreender a importância do conhecimento sobre aplicações financeiras, investimentos, e criar uma correlação biunívoca entre a matemática financeira e a dinâmica da Bolsa de Valores, de forma lúdica e divertida. 
Em síntese, espera-se que esta pesquisa sirva de suporte didático-pedagógico para os professores da área de matemática que desejam ter uma práxis inovadora e, através desta, promover a mudança do cenário atual da Educação Financeira no Brasil.

\section{Referências}

ABEFIN. Associação Brasileira dos Educadores Financeiros. Disponível em: https://abefin.org.br/. Acesso em: 31 maio 2019.

BIANCHINI, G.; GERHARDT, T.; DULLIUS, M. M. Jogos no ensino de matemática "quais as possíveis contribuições do uso de jogos no processo de ensino e de aprendizagem da matemática?" Revista Destaques Acadêmicos, Lajeado, n. 4, ano 2, p. 1-8, 2010.

BONEAPPS. Jogo Bolsa de Valores. 2019. Disponível em: https://play.google.com/store/ap ps/details? id=ru.borik.marketgame.android\&hl=pt_BR. Acesso em: 31 maio 2019.

BRASIL. Parâmetros Curriculares Nacionais do Ensino Médio. Brasília, 1997.

BRASIL. Lei de Diretrizes e Bases da Educação Nacional. Ministério da Educação e Cultura. 6. ed. Brasília, 2005.

BRASIL. Decreto Federal 7.397/2010. Disponível em: $<$ http:www.planalto.gov.br/ccivil_03/_Ato2007-2010/2010/Decreto/D7397.htm. Acesso em: 06 jun. 2019.

BRASIL. Educação financeira nas Escolas: Ensino médio. Bloco 2.1. ed. [S.1.]: Comitê Nacional de Educação Financeira - Ministério da Educação, 2014.v. 1.

BRASIL. Estratégia Nacional de Educação Financeira - Plano Diretor da ENEF. Brasília, 2017.

BRASIL. Base Nacional Comum Curricular (BNCC). Brasília, 2018.

BRASIL ESCOLA. Bolsa de Valores. 2020. Disponível em: https://www.monografias.brasilescola.uol.com.br/administracao-financas/bolsas-valores.htm. Acesso em: 20 jul. 2020.

CERBASI, G. Investimentos Inteligentes. Rio de Janeiro: Sextante, 2013.

CHIZZOTTI, A. Pesquisa em ciências humanas e sociais. São Paulo: Arquivo Kindle, 2018.

ENEF. Estratégia Nacional de Educação Financeira. Disponível em:

http://www.vidaedinheiro.gov.br/. Acesso em: 31 maio 2019. 
EU QUERO INVESTIR. O que são commodities e como investir. Disponível em: https://www.youtube.com/watch?v=CEO_pAZNeWI. Acesso em: 02 maio 2019.

KIOYOSAKI, R.; LECHTER, S. L. Pai Rico Pai Pobre: O que os ricos ensinam a seus filhos sobre dinheiro. Rio de Janeiro: Elsevier, 2000.

LOPES, M. Educação financeira na sala de aula é investir na vida fora da escola.

Disponível em: http://porvir.org/educacao-financeira-na-sala-de-aula-e-investir-na-vida-forada-escola/. Acesso em: 02 maio 2019.

OCDE. Organização para a Cooperação e Desenvolvimento Econômico. 2019. Paris, França. Disponível em: https://www.oecd.org/brazil/. Acesso em: 19 jul. 2019.

PATARO, P. R. M.; SOUZA, J. R. de. Vontade de Saber Matemática. 2. ed. São Paulo: FTD, 2012.

SILVA, M. S. da. Clube da Matemática: jogos educativos. 2. ed. Campinas, SP: Papirus, 2005.

TORO. Como investir na Bolsa de Valores? 2018a. Disponível em:

https://www.youtube.com/watch?v=PbYZZYXm6f4. Acesso em: 02 maio 2019.

TORO. O que é a Bolsa de Valores? 2018b. Disponível em:

https://www.youtube.com/watch?v=_3iaRDCqdr8. Acesso em: 02 maio 2019.

Recebido em 23 de abril de 2021.

Aprovado em 09 de junho de 2021. 